Introduction

\title{
PAST Gateways (Palaeo-Arctic Spatial and Temporal Gateways): Introduction and overview
}

\author{
Colm Ó Cofaigh ${ }^{\mathrm{a},}{ }^{*}$, Jason P. Briner ${ }^{\mathrm{b}}$, Nina Kirchner ${ }^{\mathrm{c}}$, Renata G. Lucchi ${ }^{\mathrm{d}}$, Hanno Meyer ${ }^{\mathrm{e}}$, \\ Darrell S. Kaufman ${ }^{\mathrm{f}}$ \\ a Department of Geography, Durham University, Durham DH1 3LE, UK \\ ${ }^{\mathrm{b}}$ Department of Geology, State University of New York at Buffalo, Buffalo, NY 14260, USA \\ ${ }^{c}$ Department of Physical Geography, Stockholm University, SE-106 91 Stockholm, Sweden \\ d OGS (Istituto Nazionale di Oceanografia e di Geofisica Sperimentale), Trieste, Italy \\ e Alfred Wegener Institute, Helmholtz Centre for Polar and Marine Research Unit, Potsdam, Telegrafenberg, A 4314473 Potsdam, Germany \\ ${ }^{\mathrm{f}}$ School of Earth Sciences \& Environmental Sustainability, Northern Arizona University, 928-523-7192, USA
}

\section{A R T I C L E I N F O}

\section{Article history:}

Available online $\mathrm{xxx}$

\begin{abstract}
A B S T R A C T
This special issue relates to the Second International Conference of the PAST Gateways (Palaeo-Arctic Spatial and Temporal Gateways) network which was held in Trieste, Italy in 2014. Twenty five papers are included and they address topics under four main themes: (1) The growth and decay of Arctic ice sheets; (2) Arctic sea ice and palaeoceanography; (3) Terrestrial Arctic environments and permafrost change; and (4) Holocene Arctic environmental change. Geographically the focus is circum-Arctic; the special issue includes detailed regional studies from Greenland, Scandinavia, Russia, and Arctic North America and the adjoining seas, as well as a series of synthesis-type, review papers on Fennoscandian Ice Sheet deglaciation and Holocene Arctic palaeo-climate change. The methodologies employed are diverse and include marine sediment core and geophysical investigations, terrestrial glacial geology and geomorphology, isotopic analysis of ground ice, palaeo-ecological analysis of lacustrine and terrestrial sedimentary archives, geochronology and numerical ice sheet modeling.
\end{abstract}

๑) 2016 Elsevier Ltd. All rights reserved.

\section{Introduction}

The Arctic is undergoing rapid environmental change in response to recent climate warming. This is expressed in dramatic changes to sea ice, to glacier mass balance and flow, and permafrost decay. Large marine-terminating outlet glaciers from the Greenland Ice Sheet have experienced changes to their flow velocities, in some cases accelerating, thinning and retreating (e.g., Joughin et al., 2004; Moon and Joughin, 2008), a phenomenon that has been linked to changing ocean temperatures at glacier termini (Holland et al., 2008; Straneo et al., 2010; Christoffersen et al., 2011). Some models predict the complete disappearance of Arctic Ocean sea ice this century (e.g., Holland et al., 2006; Wang and Overland, 2009) with implications for changing ocean temperatures through decreased albedo. Understanding these changes, their causes and

\footnotetext{
* Corresponding author.

E-mail address: colm.ocofaigh@durham.ac.uk (C. Ó Cofaigh).
}

subsequent impacts, as well as predicting their likely future pattern and magnitude, is a major scientific challenge. It is also a challenge with wide socio-economic importance given concerns globally about melting polar ice sheets and rising sea level. Well constrained observational records of change over the last few decades are critical to underpin numerical model predictions of future Arctic change. However, any assessment of the longer-term pattern and magnitude of these changes, the sensitivity of the Arctic to climate change beyond the period of satellite observations, and whether the on-going changes to the Arctic cryosphere are related to natural variations vs. anthropogenic forcing, relies upon the investigation of palaeo-records.

'PAST Gateways' (Palaeo-Arctic Spatial and Temporal Gateways) is an IASC (International Arctic Science Council) thematic network, the scientific goal of which is to understand Arctic environmental change during the period preceding instrumental records and across decadal to millennial timescales. A major focus of the programme is on the nature and significance of Arctic gateways, both spatial and temporal, with an emphasis on the transitions between 
major Late Cenozoic climate events such as interglacials to full glacials and full glacial to deglacial states, as well as more recent Holocene fluctuations. A meeting of ca. 70 Arctic scientists from the PAST Gateways network was held in Trieste, Italy in 2014. The meeting brought together glacial and marine geologists, palaeoceanographers, palaeoecologists, specialists in permafrost and numerical modellers to discuss records of Arctic environmental change over decadal to millennial time-scales. The meeting and the papers in this volume are organised into four major themes. (1) The growth and decay of Arctic ice sheets; (2) Arctic sea ice and palaeoceanography; (3) Terrestrial Arctic environments and permafrost change; and (4) Holocene Arctic environmental change. Many of the papers cross-cut these themes, reflecting the integrated and multi-disciplinary approach to research on Arctic environmental change.

\section{Overview of papers}

\subsection{Growth and decay of Arctic ice sheets and their geological, geophysical and geomorphological records}

A series of papers in the special issue investigate the history of the Greenland Ice Sheet during the Last Glacial Maximum to Holocene period. Hogan et al. use seabed geomorphology and acoustic facies evidence integrated with sediment core data from the Disko Trough, western Greenland, to constrain the latest Pleistocene deglaciation of the Greenland Ice Sheet. Their reconstruction reveals a detailed account of ice stream behaviour as it resided on, and eventually retreated from, the continental shelf. Their reconstruction, including a model for the development of a calving bay, underlines the importance of topographic controls during the retreat of marine outlets of large ice sheets.

Further to the north on the Greenland shelf, in Uummannaq Trough, Sheldon et al. use foraminiferal, sedimentological, and bathymetric records combined with radiocarbon dating of marine sediment cores to investigate the deglacial history of a major ice stream which drained the Greenland Ice Sheet at the LGM. They show that ice stream retreat was underway by $15 \mathrm{ka}$ and was followed quickly by incursion of the West Greenland Current suggesting that warm water may have enhanced ice retreat. This is, to date, the earliest record of Atlantic Water on the West Greenland shelf.

Larsen et al. reconstruct local glacier activity in North Greenland using ${ }^{10} \mathrm{Be}$ and OSL dating. The new chronology, which updates previous work of Möller et al. (2010) on the same deposits, is interpreted to represent a re-advance of the glacier during the Younger Dryas. The study also reviews evidence for Younger Dryas glacier activity on Greenland, and concludes that it is their study's northern location, removed from Atlantic Meridional Overturning Circulation, that resulted in the local glacier response to the Younger Dryas.

Cronauer et al. use lake sediment analysis and cosmogenic ${ }^{10} \mathrm{Be}$ exposure dating to reconstruct the Holocene history of the Greenland Ice Sheet margin on the Nuussuaq Peninsula in central West Greenland. They focus on the age of the Drygalski Moraines, a set of prominent moraines located outboard of the Little Ice Age glacial limit. On the basis of the new chronological data presented in the paper they conclude that the Greenland Ice Sheet margin was located within a couple of kilometres of its present limit and was largely stable from ca. 9.4-5.4 ka, which they relate to ocean palaeo-temperatures.

Trough mouth fans are prominent features related to ice sheet growth and glacigenic sediment delivery along glaciated continental margins (Batchelor and Dowdeswell, 2014). Using seismic reflection data and seabed bathymetry supplemented by stratigraphical information from exploration wells, Hofmann et al. investigate the long-term evolution of the Disko Bay Trough Mouth Fan on the west Greenland margin. They show that the fan evolved in three stages commencing in the Pliocene-early Pleistocene and extending to the Late Pleistocene with topography exerting a strong control on the location(s) of sediment delivery on the fan.

Stroeven et al. compile glacial geomorphological and geochronological data to provide a new timeslice reconstruction of the deglaciation of the Fennoscandian Ice Sheet. The reconstruction utilises isochrons marking every 1000 years between 22 and 13 cal kyr BP and every 100 years between 11.6 and 9.7 cal kyr BP. Stroeven et al. show that the patterns and rates of retreat varied spatially across the Fennoscandian Ice Sheet domain reflecting a range of external and internal controls. The time-slice reconstructions provide a key resource for testing and refining numerical models of ice sheet decay.

A modeling experiment is presented by Auriac et al. who compare numerical modeling of glacial isostatic adjustment and past sea-level with near-field empirical relative sea level observations in the region of the former Barents Sea Ice Sheet. They investigate six different Barents Sea Ice Sheet load scenarios and find that four agree well with observed relative sea level data from Svalbard, Franz Josef Land, Novaya Zemlya and northern Scandinavia. Auriac et al. point out that ice-thicknesses, as predicted by these four load scenarios, might however be overestimated, and they identify key locations where relative sea level and GPS data could provide support in constraining future ice sheet modeling efforts.

The paper by Kirchner et al discusses progress made in the development of numerical models of palaeo-ice sheets and why certain types of numerical solutions are inappropriate for this task. It assesses the new Ice Sheet Coupled Approximation Level (ISCAL) approach and concludes that the method has the potential to match the accuracy of Full Stokes ice sheet models over millennial timescales.

Colleoni et al. use numerical ice sheet modeling to test the hypothesis that an ice cap and an ice shelf could have grown over Beringia during the MIS 6 glaciation (140 kyrs BP) as suggested by marine geophysical investigations from the Arctic Ocean (e.g., Niessen et al., 2013). Results of the modeling experiment show that during MIS6 an ice cap develops over Beringia and connects to the Eurasian Ice Sheet resulting in a combined ice volume of 6-14 m SLE. The ice cap generates an ice shelf of dimensions comparable with or larger than the present-day Ross Ice Shelf in West Antarctica. Key controls on ice shelf extent in the models are the ice flux through the grounding line and choice of calving and basal melting parameters.

\subsection{Arctic sea ice and palaeoceanography}

Löwemark et al. analyse sediment cores from the Lomonosov Ridge and the Morris Jesup Rise to reconstruct the history of sea ice conditions in the Arctic Ocean north of Greenland over the last two glacial cycles. They find evidence that suggests that sea ice cover and sedimentation were notably different during interglacials MIS1 and MIS 5, as well as during glacials MIS2 and MIS6. This leads them to suggest that previous stages may be poor analogues for future scenarios, unless the physical processes controlling sea ice conditions and ocean circulation are better understood.

A detailed morphological, seismostratigraphical, lithological and sedimentological analysis of a sediment drift in Kveithola trough in the northwestern Barents Sea is presented by Rebesco et al. They propose that the genesis of the complex "Kveithola Drift" is strongly controlled by brine enriched shelf-waters, the formation of which is inferred to have started around $13 \mathrm{cal}$ ka BP. The authors 
suggest that conditions leading to atmospheric cooling of surface waters and/or the presence of coastal polynias have persisted on the western Barents shelf since that time, and point out that investigations focusing on the response of the bottom current regime to changes in e.g., grounded land ice dynamics, and sea ice cover, need to be addressed in the future.

Werner et al. reconstruct sea surface and subsurface temperature variability in eastern Fram Strait over the last 12 kyr through a high resolution micropalaeontological and biomarker study. They show warm sea surface to subsurface temperatures persisted until ca. $5 \mathrm{ka}$ BP. Maximum temperatures at around $10 \mathrm{ka}$ BP are suggested to relate to strong advection of Atlantic Water into Eastern Fram Strait around that time. After 5 ka the contribution of Atlantic Water decreases and this is associated with a decrease in subsurface temperatures reaching a minimum between $4 \mathrm{ka}$ and $3 \mathrm{ka}$. They show that during the late Holocene there was decoupling of surface and subsurface ocean waters probably related to changes in North Atlantic gyre activity.

Kaparulina et al. present a provenance study using mineralogical and geochemical data of a sediment core from the Lomonosov Ridge in the central Arctic Ocean. They use the data to determine the trajectory of ice-transport from circum-Arctic sources and assess associated variability in sediment sources and delivery between MIS65 and MIS4-3. They show that the main source of material during the earlier time interval was the Amerasian margin but during MIS4-3 this shifted to the Eurasian margin.

\subsection{Terrestrial Arctic environments and permafrost change}

Lake El'gygytgyn in Far East Russia comprises a unique record of Arctic climate evolution of the past 3.6 Ma. Sediment sequences recovered by the El'gygytgyn Drilling Project in the centre of the lake and its vicinity represent the longest continuous terrestrial archive in the Arctic. Wennrich et al. review results obtained during the on-going multi-proxy study at Lake El'gygytgyn. The 3.6 Ma old complex lacustrine sediment record is combined with permafrost and impact records to increase the overall knowledge of this unique archive for the understanding of long-term climatic variability in the Arctic.

Andreev et al. perform a high-resolution pollen study including a quantitative biome reconstruction of Late Pliocene and Early Pleistocene climate history at Lake El'gygytgyn. The authors demonstrate that the lake record is an excellent archive of vegetation and climate change between about 2.7 and 2.5 Myr BP. Both this study and that of Wennrich et al. (this volume) clearly illustrate the susceptibility of this high Arctic lake to orbitally-triggered regional and global climate change.

Schirrmeister et al. use pollen and macrofossil data from a rare man-made tunnel that exposes a frozen (permafrost) sediment section in interior Alaska, USA. Their detailed work documents the vegetation and environmental history of the region spanning 90 kyr from MIS 5 to MIS 2.

Fritz et al. study a radiocarbon-dated permafrost core from a polygon field within a drained thermokarst lake in the western Canadian Arctic. They used pollen, diatoms, macrofossils and water isotope analysis to derive not only a paleoenvironmental reconstruction, but also a framework for the development of ice wedge polygons under changing climatic conditions.

Using Uranium-Thorium disequilibrium dating Wetterich et al. show that permafrost along the coast of the East Siberian Dmitry Laptev Strait and preserved beneath the MIS2-3 Yedoma Ice Complex was formed during MIS5. Isotopic analysis and palynological investigation reveal winter conditions that were colder than MIS3 interstadial and warmer than during MIS2 stadial as well as tundrasteppe vegetation and harsh summer conditions.

\subsection{Holocene Arctic environmental change}

Three papers in the special issue provide major regional summaries of Holocene climate history across the western Arctic, building on an extensive compilation of previously published proxy climate records (Sundqvist et al., 2014). The coordinated set of papers are part of the Arctic Holocene Transitions project and compare the Arctic Holocene dataset with other available paleoenvironmental evidence to reconstruct spatial-temporal patterns of temperature change and to quantify the most prominent trends represented by a large variety of palaeo-evidence from terrestrial and marine sites north of $58^{\circ} \mathrm{N}$. The papers focus on eastern Beringia (northwestern North America; Kaufman et al.), Arctic Canada and Greenland (northeastern North America; Briner et al.) and the North Atlantic - Fennoscandia region (Sejrup et al.).

In eastern Beringia, composite proxy-based time series were compared with glacier and lake-level fluctuations, terrestrial water-isotope records, sea-ice and sea-surface temperature analyses, as well as peatland and thaw-lake initiation frequencies. During the early Holocene, rather than a prominent thermal maximum as suggested previously, the newly compiled palaeoevidence indicates that temperatures were highly variable, at times both higher and lower than present, although the overall lowest average temperatures occurred during the earliest Holocene. During the middle Holocene, temperatures increased more uniformly across the region to a maximum between 7 and $5 \mathrm{ka}$, as reflected in most proxy types. In Arctic Canada and Greenland, the Holocene thermal maximum occurred earlier in the northern and eastern parts of the region and later, and more diffusely, in the south and west. The Greenland Ice Sheet retracted to its minimum extent between 5 and $3 \mathrm{ka}$, consistent with other palaeo-records from around Greenland that show a shift to cooler conditions around that time. In the North Atlantic - Fennoscandian region, the primary temperature trend for terrestrial and surface marine proxies is more uniform than in other regions, with peak warmth between 8 and $6 \mathrm{ka}$. The secondary pattern is similar to the Canadian Arctic - Greenland region, with peak warmth occurring earlier in the north than the south. A different pattern is indicated by proxies that record near-surface marine conditions. Collectively, the three new regional reviews have clarified the millennial-scale trends in Holocene temperature, improved understanding of the mechanisms of millennial- and sub-millennial-scale climate change, and have highlighted proxy biases and future research priorities.

The pair of papers by Chapligin et al. and Narancic et al. uses mutli-proxy data from sediment cores from Nettilling Lake, eastern Canadian Arctic. Their record, which features the first diatom-based $\mathrm{d} 180$ record from the region, is used to quantify major paleoenvironmental changes spanning the past 8300 years, and includes new insights into the timing and character of post-glacial emergence of this isolation basin.

Biskaborn et al. provide data on Holocene climate change from a lake-sediment record from northeast Siberia. They use diatoms and sediment geochemistry to infer winter and summer temperature in a core that spans the Holocene but with basal sediments that may date to $\sim 38 \mathrm{ka}$. They conclude that peak Holocene temperatures occurred at their site from 8.9 to $4.5 \mathrm{ka}$, and they argue for regional controls on the timing, onset, and ending of peak Holocene warmth.

Klemm et al. present a multi-proxy analysis of a lake sediment core from the southern Taymyr Peninsula, Northern Siberia to investigate Holocene environmental change over the last $7.1 \mathrm{ka}$. The data indicates an overall cooling of summer temperatures by about $2{ }^{\circ} \mathrm{C}$ since $7 \mathrm{ka}$ until the establishment of modern conditions around $3 \mathrm{ka}$. This temperature decrease reflects the associated reduction in 
larch forest density and suggests that the ecosystem was highly sensitive to Holocene climate variations.

\section{Acknowledgements}

We thank ICARP III and IASC for their contribution to the funding of the Trieste meeting.

\section{References}

Batchelor, C.L., Dowdeswell, J.A., 2014. The physiography of high Arctic cross-shelf troughs. Quat. Sci. Rev. 92, 68-96.

Christoffersen, P., Mugford, R.I., Heywood, K.J., Joughin, I., Dowdeswell, J.A., Syvitski, J.P.M., Luckman, A., Benham, T.J., 2011. Warming of waters in an east Greenland fjord prior to glacier retreat: mechanisms and connection to largescale atmospheric conditions. Cryosphere 5, 701-714.

Holland, M.M., Bitz, C.M., Tremblay, B., 2006. Future abrupt reductions in the summer Arctic sea ice. Geophys. Res. Lett. 33, L23503.

Holland, D.M., Thomas, R.H., de Young, B., Ribergaard, M.H., Lyberth, B., 2008. Acceleration of Jakoshavn Isbrae triggered by warm subsurface ocean waters. Nat.
Geosci. 1, 659-664

Joughin, I., Abdalati, W., Fahnestock, M., 2004. Large fluctuations in speed on Greenland's Jakobshavn Isbræ glacier. Nature 432, 608-610.

Moon, T., Joughin, I., 2008. Changes in ice front position on Greenland's outlet glaciers from 1992 to 2007. J. Geophys. Res. 13 (F2).

Möller, P., Larsen, N.K., Kjær, K.H., Funder, S., Schomacker, A., Linge, H., Fabel, D, 2010. Early to middle Holocene valley glaciations on northernmost Greenland. Quat. Sci. Rev. 29 (25-26), 3379-3398.

Niessen, F. Hong, J.K., Hegewald, A. Matthiessen, J. Stein, R., Kim, H., Kim, S. Jensen, L., Jokat, W., Nam, S., et al., 2013. Repeated Pleistocene glaciation of the east Siberian continental margin. Nat. Geosci. 6, 842-846.

Straneo, F., Hamilton, G.S., Sutherland, D.A., Stearns, L.A., Davidson, F. Hammill, M.O., Stenson, G.B., Rosing-Asvid, A., 2010. Rapid circulation of warm subtropical waters in a major glacial fjord in east Greenland. Nat. Geosci. 3, $182-186$.

Sundqvist, H.S., Kaufman, D.S., McKay, N.P., Balascio, N.L., Briner, J.P., Cwynar, L.C., Sejrup, H.P., Seppa, H., Subetto, D.A., Andrews, J.T., Axford, Y., Bakke, J. Birks, H.J.B., Brooks, S.J., et al., 2014. Arctic Holocene proxy climate database new approaches to assessing geochronological accuracy and encoding climate variables. Clim. Past 10 (4), 1605-1631.

Wang, M., Overland, J.E., 2009. A sea ice free summer arctic within 30 years? Geophys. Res. Lett. 36 (L037820). 